\title{
Erratum: Pure-quartic solitons
}

Andrea Blanco-Redondo, C. Martijn de Sterke, J.E. Sipe, Thomas F. Krauss, Benjamin J. Eggleton \& Chad Husko

Nature Communications 7:10427 doi: 10.1038/ncomms10427 (2016); Published 29 Jan 2016; Updated 9 Mar 2016

The original version of this article contained an error in the spelling of the author C. Martijn de Sterke, which was incorrectly given as de Sterke C. Martijn. This has now been corrected in both the PDF and HTML versions of the article.

(c) (i) This work is licensed under a Creative Commons Attribution 4.0 International License. The images or other third party material in this article are included in the article's Creative Commons license, unless indicated otherwise in the credit line; if the material is not included under the Creative Commons license, users will need to obtain permission from the license holder to reproduce the material. To view a copy of this license, visit http://creativecommons.org/licenses/by/4.0/ 